\title{
THE CONCEPT OF “WORKER" UNDER THE PRINCIPLE OF FREE MOVEMENT OF WORKERS AND ITS IMPLICATIONS FOR THE PROTECTION OF WORKERS IN THE EUROPEAN UNION
}

\begin{abstract}
The competence of the European Union in the field of labour law is limited to the support, complementation and coordination of the activities of the Member States in the exhaustive areas of labour law. The diversity of national definition of legal concepts used in EU challenges the harmonisation of national legal orders and their gradual convergence. The lack of consistency between Member States in respect of determination of who qualifies as a "worker" in national legal orders lead to the differences between Member States, as regards the application of the minimum standards to the same category of persons performing a paid job. This can undermine the objectives pursued by directives and may jeopardise their effectiveness. A uniform concept of "worker" has not yet been developed at the EU level. The starting point for any discussion about the concept of "worker" in EU law is the definition of "worker" provided for the principle of free movement of workers enshrined in Art. 45 of TFEU. Given the non-discriminatory purpose of the concept of worker under the principle of free movement of workers, this article is going to consider whether this concept has the potential for broader protection of workers in the EU.
\end{abstract}

Słowa kluczowe: pracownik, Unia Europejska, swobodny przepływ pracowników, pierwotne prawo Unii Europejskiej, wtórne prawo Unii Europejskiej

Keywords: worker, European Union, free movement of workers, primary European Union law, secondary European Union law

ASJC: 3308 , JEL: K31

\section{Introduction}

The competence of the European Union (hereinafter referred to as: "EU") in the field of labour law involves the support, complementation and coordination the activities of the Member States in the exhaustive areas of labour law (Art. 153 and 156 of Treaty on the 
Functioning of the European Union; OJ C 2010/83, hereinafter referred to as: "TFEU," p. 1). This entails, as Art. 153(2)(b) of TFEU states, the adoption by means of a directive of the minimum standards to be implemented by Member States. The harmonisation of national legal orders and their gradual convergence challenged the diversity of national definitions of legal concepts used in EU labour law legislation. The concept of a "worker" serves as a good example of this issue, when it sets out the personal scope of EU labour law legislation. The lack of consistency between Member States in respect of determination of who qualifies as a "worker" in national legal orders leads to the differences between Member States as regards the application of the minimum standards to the same category of persons performing a paid job. This can undermine the objectives pursued by directives and may jeopardise their effectiveness.

A uniform concept of "worker" has not yet been developed at the EU level. The starting point for any discussion about the concept of "worker" in EU law is the definition of "worker" provided for the principle of free movement of workers enshrined in Art. 45 of TFEU, which is one of the four pillars of the European single market. The concept of "worker" is at the very heart of the principle free movement of workers, since the creation of a genuine common market without internal frontiers needs to ensure that each Member State guarantees that nationals of other Member States receive the same treatment as that guaranteed to its own nationals as regards access to its labour market (Art. 45(2) of TFEU; CJEU cases: Hoekstra, C-75/63, EU:C:1964:19; Levin, C-53/81, EU:C:1982:105, p. 7). The development of a single definition of "worker" for the purpose of free movement of workers is based on the assumption that if the definition of this term were a matter within the competence of national law of Member States, it would then be possible for each Member State to unilaterally modify the meaning of the concept of "worker" and to frustrate at will the protection afforded by the principle of free movement of workers to certain categories of person (CJEU cases: Hoekstra; Levin, p. 11). The concept of "worker" under Art. 45 of TFEU has an autonomous meaning, which means that this concept may not be defined by reference to the national laws of the Member States, which cannot interpret this concept differently when implementing the principle of free movement of workers (CJEU case: LawrieBlum, C-66/85, EU:C:1986:284).

Given the non-discriminatory purpose of the concept of worker under the principle of free movement of workers, it is then worth considering whether this concept has the potential for broader protection of workers in the EU.

\section{The concept of "worker"-a supranational meaning}

Art. 45 does not provide a definition of the concept of "worker." It also cannot be found in Regulation No 492/2011 on freedom of movement for workers within the Union. The concept of "worker" for the purpose of free movement of workers was developed by the Court of Justice of the European Union (hereinafter referred to as: "CJEU”). It 
is based on the so-called Lawrie-Blum formula, adopted by the CJUE in the LawrieBlum case (Lawrie-Blum, p. 15). Under this formula, the concept of "worker" is determined by the "existence of a relationship of subordination vis-á-vis the employer, irrespective of the nature of that relationship, the actual provision of services and the payment of remuneration." Under this formula, any person who "is obliged to provide services to another in return for monetary reward and who is subject to the discretion or control of the another person as regards the way in which the work is done" (LawrieBlum, p. 14) must be regarded as a "worker." In the earlier case Levin (p. 17), the CJEU stated that this covers only "effective and genuine activities, to the exclusion of activities on such a small scale as to be regarded as purely marginal and ancillary." The EU concept of "worker" is defined by the reference to the objective criteria "distinguished by reference to the rights and duties of the persons concerned" (Lawrie-Blum, p. 17), namely the reality of the relationship rather than the formal terms of the contract. The concept of "worker" developed in Lawrie-Blum and Levin was upheld in later caselaw (among others see in particular cases: Martinez Sala, C-85/96, EU:C:1998:217; Collins, C-138/02, EU:C:2004:172, p. 26; Trojani, C-456/02, EU:C:2004:488, p. 15; Neidel, C-337/10, EU:C:2012:263, p. 23; SARL, C-432/14, EU:C:2015:643, p. 22).

The definition of "worker" developed for the purpose of free movement of workers is shaped by the "traditional" defining structural elements of the employment relationship, which are: subordination, bilaterality and continuity. These elements set out the borderline for a binary division between an employment relationship and other work relations. Notably, the concept of "worker" under Art. 45 of TFEU does not cover the situation where a person is not in a relation of subordination, meaning as a "personal dependency," but only in a form of "economic dependency," since it works in person for only one of a very small number of contractual partners (Risak, Dullinger 2018, p. 46). Such workers are considered by the CJEU to be self-employed, thus enjoy an autonomous free movement right to establishment (Art. 49 of TFEU) and freedom to provide services (Art. 56 of TFEU; also: Allonby, C-256/01, EU:C:2004:18, p. 68; FNV Kunsten, C-413/13, EU:C:2014:2411, pp. 35, 36, 38).

The CJEU represents an inclusive approach to these defining structural elements of the employment relationship, since a restrictive interpretation is considered to be contrary to the assumptions underlying the principle of free movement of workers (among others see in particular cases: Levin, p. 12, 13, 15; Lawrie-Blum, p. 16; Bettray, C-344/87, EU:C:1989:226, p. 11; Raulin, C-357/89, EU:C:1992:87, p. 10; Meeusen, C-337/97, EU:C:1999:284; Ninni-Orasche, C-413/01, EU:C:2003:600, p. 23). These elements are interpreted on a case-by-case basis considering of all factors and circumstances characterising the relationship between the parties (see in particular cases: Danosa, C-232/09, EU:C:2010:674, p. 46; Holterman Ferho Exploitatie BV and Others vs. F.L.F. Spies von Büllesheim, C-47/14, EU:C:2015:574, p. 46; Allonby, p. 69). A broad approach to the concept of "worker" seeks to confront the challenges to regulation of a growing number of working relationships that do not fall within the boundaries of the employment relationship set out by a strict understanding of the concept 
of "subordination" and "continuity", mainly those characterised by an irregular income, on-call schedules, involve fragmented working hours, or are provided on a casual basis. This is in line with the preamble to Regulation No 492/2011, which contains a general affirmation of the right of free movement of all workers in Member States, irrespective of whether they are permanent, seasonal or frontier workers or whether they pursue their activities for the purpose of providing services, and recently established a European Pillar of Social Rights that extends the principle enshrined to all workers regardless of the type and duration of their employment relationship (see: Recital 15 Commission Recommendation 16 April 2017 on the European Pillar of Social Rights, Brussels, 26 April 2017, C(2017)2600 final).

Whereas the CJEU uses a "traditional" indicia for determining a "subordination," meaning a manifestation of the direction of the employer over the worker (among others see, in particular cases: Lowrie-Blum, $\$ \$ 17,18$; Allonby, $₫ 72$; Danosa, $₫ 46$; Becu, C-22/98, EU:C:1999:419, p. 26), a clear tendency in caselaw for a broader understanding of this concept is visible, from strict and hierarchical, regarding the time, place and the way the task is carried out by an employee (among others see in particular cases: LowrieBlum, pp. 17, 18; Allonby, p. 72; Danosa, p. 46; Becu, p. 26), to a more flexible one. In the O'Brien case (C-393/10, EU:C:2012:110, pp. 34, 35, 38, 51; see also: Ruhrlandklinik gGmbH, C-216/1,5 EU:C:2016:883), the CJEU has made allowances for greater autonomy and independence of the employee as to the organisation of work and the way the tasks are performed. The "continuity" as an element of the concept of "worker" is manifested as an exclusionary criterion that requires that the activity is not "purely marginal" and "ancillary." The CJEU confirms that qualitative and quantitative national criteria that refer to the qualifying period of employment, amount of income derived from, or number of hours of work, are not decisive when deciding about the status of a "worker." The recent caselaw of the CJEU provides some guidelines that may be useful for such an interpretation, in which the CJEU analysed the extent of the activity concerned. The CJEU held that it cannot, in itself, qualify work as "marginal" and "ancillary," thus excluding a person concerned from the status of "worker:" short duration of employment, fixed from the outset (Ninni-Orasche, p. 25; Raulin, p. 11) or provided on the basis of a framework of "work on demand" (Wippel, C-313/02, EU:C:2004:607, p. 40); a limited number of hours of work (Lawrie-Blum, p. 20; Genc, C-14/09, EU:C:2010:57, p. 26), including that provided in the framework of an on-call contract (Raulin, p. 11, 14); a limited amount of remuneration, including remuneration lower than the starting salary in a given profession (Lawrie-Blum, p. 20), and lower than the minimum guaranteed remuneration in a Member State or lower than what is considered to be a minimum in Member States required for subsistence, irrespective of whether such an income is supplemented with other income of a worker (Levin; Fenoll, C-316/13, EU:C:2015:200; Genc, p. 25) or when a remuneration is largely provided by subsidies from public funds (Bettray, p. 15); the lower productivity of a person employed in the scheme of social employment (Bettray, p. 15); or work in return for payment in kind (Steymann, C-196/87, EU:C:1988:475; Payir, C-294/06, EU:C:2008:36). 


\section{The application of the concept of "worker" to EU primary and secondary law}

In the case Martinez Sala (p. 31), the CJEU pointed out that the definition of worker in EU law "varies according to the area in which the definition is to be applied." In the Navas case (C-13/05, EU:C:2006:184, p. 41; see also: Meerts, C-116/08, EU:C:2009:645, p. 41), the CJEU has expressed its desire for uniform application of EU law, which requires the need to given "an autonomous and uniform interpretation" of a provision of EU law, which makes no express reference to the law of Member States, "having regard to the context of the provision and the objective pursued by the legislation in question." This confirms that when defining the concept of a "worker," the ratio legis of the relevant provisions of EU primary and secondary legislation must be taken into account.

The contextual and teleological interpretation was applied by the CJEU in the case of Allonby (p. 64) when determining the term "worker" used in Art. 157 of TFEU (ex Art. 141 of EC). The decision in Allonby was built around the observations made by the CJEU in the case of Angonese (C-281/98, EU:C:2000:296, p. 35), where it pointed out that Art. 48 of TFEU (also Art. 45) "lays down a fundamental freedom and which constitutes a specific application of the general prohibition of discrimination," therefore "like Art. 119 EC (Art. 157 of TFEU) it is designed to ensure that there is no discrimination on the labour market." The CJEU then found that the definition of "worker" developed for the purpose of free movement of workers needs to be imported in the area of equal pay for men and women as contained in Art. 157 of TFEU (Allonby, $\$ 67$; Tomaszewska 2011, pp. 285-288). Given that Art. of 157 of TFEU constitutes a specific expression of the general principle of equality and non-discrimination, it is clear that the concept of "worker" under Art. 45 of TFEU has the potential to determine the scope ratione personae of the general principle of discrimination as regards to other "conditions of employment." The same rationale, as indicated by the CJEU in the Allonby case, apply to the personal scope of anti-discrimination secondary law, in particular Directive 2006/54/EC, Directive 2000/78/EC and Directive 2000/43/EC, that share with Art. 157 of TFEU the common trait of being adopted to put into effect a general principle of equal treatment (Tomaszewska 2011, pp. 289-291).

The argument of "uniform application" of EU law, as indicated in the Navas case, lies behind the reasoning for claiming an autonomous concept of "worker" developed for the purpose of free movement of workers, in a few socially-oriented directives that do not include an explicit definition of "worker" and do not refer to the nationally accepted definition of this concept. As follows from the CJEU decision in the Kiiski case (C-116/06, EU:C:2007:536, pp. 24, 25), the concept of "pregnant worker" in Directive 92/85/EEC (Maternity Protection Directive) has a "Community meaning, even if, in respect of one element of that definition, namely that relating to the method of communication of her condition to her employer, it refers back to national legislation and/ or national practice" (on the same jurisprudential line see also: Danosa, p. 39). In the case Union syndicale Solidaires Isére (C-428/09, EU:C:2010:612, p. 28) "an autonomous meaning" of the concept of "worker specific to European Union law" was given by the 
CJEU for the purpose of applying Directive 2003/88/EC (Working Time Directive; this jurisprudential line was upheld in later case-law, e.g. Fenoll, pp. 25, 27). The same autonomous concept of "worker" was also embraced in the context of Directive 98/59/ EC (Collective Redundancy Directive; Commission vs. Italy, C-596/12, EU:C:2014:77, pp. 16,17) and in Directive 2008/95/EC (Employer Insolvency Directive; Balkaya, C-229/14, EU:C:2015:455, p. 34). With respect to these Directives, which share a common aim to achieve harmonisation of national rules in a given area, the autonomous concept for the personal scope of its application serves to ensure comparable protection for worker's rights in different Member States (see the reasoning used by CJEU in case Balkaya, $\$ 32$ as a presumption for an argument for an autonomous concept of "worker"). Attempts to provide a codified definition of "worker" for the purposes of the proposed Directive on Transparent and Predictable Working Conditions, which would be based on the established caselaw of the CJEU, as developed since Lawrie-Blum, has so far failed to reach a solution (more on this issue see: Bednarowicz 2019, pp. 604-623).

\section{The EU's autonomous concept of "worker" vs. nationally accepted definitions}

The personal scope of most of the Directives is shaped by reference to the nationally accepted definition of "worker," by stating that they cover those "who have an employment contract or employment relationship as defined by the law, collective agreements and/or practice in force in each Member State." This is the case of Directive 2001/23/ EC (Transfer of Undertakings Directive; Art. 2(1)(d)), Directive 2010/18/EU (Parental Leave Directive; Clause 1(2)), Directive 2008/104/EC (Temporary Agency Work Directive; 3(1)(a)(c)), Directive 97/81/EC (Part-Time Work Directive Clause 2(1)) and Directive 99/70/EC (Fixed-Term Work Directive Clause 2(1)).

Initially, in applying all these Directives, the CJEU refused to confirm an autonomous concept of "worker." In the well-known of case Danmols Inventar (C-105/84, EU:C:1985:331, pp. 26,27), it held that, while the Transfer of Undertakings Directive "is intended to achieve only partial harmonisation ... it is not intended to establish a uniform level of protection throughout the Community on the basis of common criteria," then that Directive:

... may be relied upon only by persons who are, in one way or another, protected as employees under the law of the Member State concerned. If they are so protected, the Directive ensures that their rights arising from a contract of employment or an employment relationship are not diminished as a result of the transfer.

The CJEU relied on an argument of "partial harmonisation" in later cases-Collino and Chiappero (C-343/98, EU:C:2000:441, pp. 36, 37) and Scattolon (C-108/10, EU:C:2011:542, p. 39). The position adopted in the case of Danmols Inventar was re-affirmed by the 
CJEU in the case of Wippel (p. 40) with respect to the application of the Part-Time Work Directive (respectively other so-called atypical work Directives), that is seeking to achieve a partial harmonisation in respect of working conditions. The CJEU confirmed the absolute power of the Member State to define the concept of "workers who have an employment contract or an employment relationship" under the Part-Time Work Directive. This meant, in practice, the exclusion of certain a category of atypical work from the protection provided by atypical directives dependant on the national legal definitions and practices and led to differences in the protection between Member States.

The O'Brien case (pp. 34, 35, 38, 51) demonstrates a clear departure from the approach in Danmols Inventar. The CJEU has held that the discretion granted to the Member States in respect of the definition of "worker" is not unlimited. "In that regard, Member States may not apply rules which are liable to jeopardise the achievement of the objectives pursued by a directive and, therefore, deprive it of its effectiveness." Accordingly that:

... the definition of "workers who have an employment contract or an employment relationship" for the purposes of Clause 2.1 of the Framework Agreement on part-time work will have an effect on the scope and effectiveness of the principle of equal treatment enshrined in that agreement.

For this reason, the power of Member States to define the concept of "worker" may not lead to arbitrary exclusion of certain categories of persons from the protection offered by Directive 97/81and that framework agreement that is possible only if the relationship concerned, "by its nature, is substantially different from that between employers and their employees falling, according to national law, under the category of workers." The argument of "effet utile" of EU law was applied by the CJEU in the recent case of Ruhrlandklinik gGmbH (pp. 29, 36) with regard to the Temporary Agency Workers Directive.

The evolution in the CJEU caselaw in the approach to the ratione personae of Directives that refer to a nationally accepted definition of "worker" has been recently literally affirmed in a Directive on Work-Life Balance for Parents and Carers (Art. 2) and in a proposal for a Directive on Transparent and Predictable Working Conditions in the European Union (Art. 1(2); that will repeal the Written Statement Directive 91/533/EC), that both refer to national law, but "with consideration" of the case law of the CJEU. This reflects that the intention of the EU legislator is not to replace national legislation in respect of the definition of a "worker," but to ensure the effectiveness of EU law ("effet utile" argumentation).

\section{Conclusions}

This article enabled us to draw some general conclusions regarding the application of the autonomous concept of "worker" developed in the EU for the purpose of the principle of free movement of workers.

Firstly, we may observe a clear tendency for adopting a uniform concept of "worker" in relation to other areas of EU labour law, which is based on the definition of a "worker" set 
out by the CJEU in the case of Lawrie-Blum with regard to the free movement of workers. A reason for claiming the autonomous concept of "worker," and extending the principle of free movement of workers, is structured around an argument of uniform application of EU law that shares a common aim, which is to ensure comparable protection for worker's rights in the different Member States. As in the case of free movement of workers, the broader harmonisation of national legal orders under the idea of equal treatment, of which the uniform concept of "worker" is an integral part, has gone beyond its sole market creation purpose and become perceived by its independent social goals.

Secondly, the EU autonomous concept of "worker" serves as a reference point to control a nationally-accepted definition of "worker" when implementing Directives whose personal scope of application is shaped by the reference to the national law of Member States. The argument of "effet utile" sets strict boundaries for such control by the CJEU, which is limited to ensuring the effectiveness of EU legislation that may be frustrated by the full discretion given to Member States in this regard. The power of the CJEU to scrutinise a nationally accepted definition of "worker," accepted in recent caselaw, mitigates the risk of exclusion a certain category of workers, especially workers in very atypical work relations, from protection provided in Directives, when it depends on a different national definition of the concept of "worker,"

Thirdly, the argument of effective protection of all persons who provide personal and paid work, raises a question about the redefinition of the concept of "worker" to include those who are in a situation comparable to workers in the traditional sense of this concept, developed by the CJEU in the case of Lawrie-Blum, since having no or at least little bargaining power to perform fully on the market as an genuine independent contractor. The extension of the concept of "worker" to the element of "dependency" would imply a departure from the binary division established in CJEU caselaw between workers and the self-employed based on the element of "subordination."

\section{References}

Bednarowicz B. (2019) Delivering on the European Pillar of Social Rights: The New Directive on Transparent and Predictable Working Conditions in the European Union, "Industrial Law Journal," Vol. 48, Issue 4.

Risak M., Dullinger T. (2018) The Concept of "Worker" in EU law. Status Quo and Potential for Change, Brussels.

Tomaszewska M. (2011) Prawo integracji stosunku pracy. Między jednościa a różnorodnościa, Gdańsk.

\section{Legal acts}

Treaty on the Functioning of the European Union of 26 October 2012, OJ C 2010/83.

Regulation (EU) No 492/2011 of the European Parliament and of the Council of 5 April 2011 on freedom of movement for workers within the Union, OJ L 2011/141. 